Lack of evidence for regulation of cardiac P-type ATPases and MAP kinases in transgenic mice with cardiac-specific overexpression of constitutively active $\alpha_{1 B}$-adrenoceptors

F. Barreto, D.C. Rezende, C.B.V. Scaramello, C.L.M. Silva, V.M.N. Cunha, A. Caricati-Neto, A. Jurkiewicz, F. Noël and L.E.M. Quintas

The Brazilian Journal of Medical and Biological Research is partially financed by

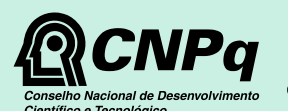
da Ciência e Tecnolório

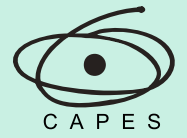

Ministério da Educação

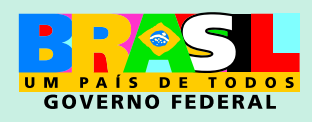




\title{
Lack of evidence for regulation of cardiac P-type ATPases and MAP kinases in transgenic mice with cardiac-specific overexpression of constitutively active $\alpha_{1 \mathrm{~B}}$-adrenoceptors
}

\author{
F. Barreto1, D.C. Rezende ${ }^{1}$, C.B.V. Scaramello², C.L.M. Silva1 , V.M.N. Cunha1, \\ A. Caricati-Neto ${ }^{3}$, A. Jurkiewicz ${ }^{3}$, F. Noël ${ }^{1}$ and L.E.M. Quintas ${ }^{1}$ \\ ${ }^{1}$ Programa de Farmacologia, Instituto de Ciências Biomédicas, Universidade Federal do Rio de Janeiro, \\ Rio de Janeiro, RJ, Brasil \\ ${ }^{2}$ Departamento de Fisiologia e Farmacologia, Instituto Biomédico, Universidade Federal Fluminense, \\ Niterói, RJ, Brasil \\ ${ }^{3}$ Departamento de Farmacologia, Universidade Federal de São Paulo, São Paulo, SP, Brasil
}

\begin{abstract}
The regulatory function of $\alpha_{1 \mathrm{~B}}$-adrenoceptors in mammalian heart homeostasis is controversial. The objective of the present study was to characterize the expression/activity of key proteins implicated in cardiac calcium handling $\left(\mathrm{Na}^{+} / \mathrm{K}^{+}-\mathrm{ATPase}\right.$ and $\mathrm{Ca}^{2+}$-ATPases) and growth (ERK1/2, JNK1/2 and p38) in mice with cardiac-selective overexpression of constitutively active mutant $\alpha_{1 \mathrm{~B}}$-adrenoceptor $\left(C A M \alpha_{1 \mathrm{~B}}-\mathrm{AR}\right)$, which present a mild cardiac hypertrophy phenotype. Immunoblot assays showed that myocardial plasma membrane $\mathrm{Ca}^{2+}$-ATPase (PMCA) expression was increased by $30 \%$ in $\mathrm{CAMa}_{1 \mathrm{~B}}-\mathrm{AR}$ mice $(\mathrm{N}=6, \mathrm{P}<0.05)$, although there was no change in sarco/endoplasmic reticulum $\mathrm{Ca}^{2+}$-ATPase (SERCA2) expression. Moreover, total Ca ${ }^{2+}-\mathrm{ATPase}$ activity was not modified, but a significant increase in the activity of the thapsigargin-resistant (PMCA) to thapsigargin-sensitive (SERCA) ratio was detected. Neither $\mathrm{Na}^{+} / \mathrm{K}^{+}$-ATPase activity nor the expression of $\alpha_{1}$ and $\alpha_{2}$ subunit isoforms was changed in $\mathrm{CAMa}_{1 \mathrm{~B}}-\mathrm{AR}$ mouse hearts. Moreover, immunoblot assays did not provide evidence for an enhanced activation of the three mitogen-activated protein kinases studied in this stage of hypertrophy. Therefore, these findings indicate that chronic cardiac $\alpha_{1 B}-A R$ activation in vivo led to mild hypertrophy devoid of significant signs of adaptive modifications concerning primary intracellular calcium control and growth-related proteins, suggesting a minor pathophysiological role of this adrenergic receptor in mouse heart at this stage of development.
\end{abstract}

Key words: $\alpha_{1 \mathrm{~B}}$-adrenoceptors; $\mathrm{Ca}^{2+}$-ATPases; Cardiac hypertrophy; $\mathrm{Na}^{+} / \mathrm{K}^{+}$-ATPase; Mitogen-activated protein kinases

\section{Introduction}

In mammalian heart, adrenoceptors (AR) mediate myocyte contraction and growth induced by the sympathetic nervous system. The $\beta_{1}-A R$ is the most abundant cardiac AR subtype and its functional importance has been extensively studied (1). However, other AR subtypes are present in the heart and their relevance to pathophysiological conditions has been studied in recent years $(2,3)$. The $\alpha_{1}-A R$, which primarily activates Gaq protein-coupled phospholipase $C \beta$ signal transduction, has been implicated mostly in cardiomyocyte growth in vitro (2-5). In vivo, however, unbiased myocardial responses are impossible to evaluate conclusively because of the vasoactive effect of $\alpha_{1}$-AR agonists. In addition, the restricted number of appropriate subtype-selective ligands, especially for $\alpha_{1 B}-A R$ $(1,2)$, makes the elucidation of specific effects of different $\alpha_{1}$-AR particularly challenging.

In order to overcome these drawbacks, transgenic mouse models overexpressing distinct myocardial-targeted

Correspondence: L.E.M. Quintas, Laboratório de Farmacologia Bioquímica e Molecular, Instituto de Ciências Biomédicas, Universidade Federal do Rio de Janeiro, Av. Carlos Chagas Filho, 373, CCS, Bloco J, Sala J01-017, 21941-902 Rio de Janeiro, RJ, Brasil. Fax:+55-21-2562-6732. E-mail: Iquintas@farmaco.ufrj.br/lquintas@ufrj.br

The present address of F. Barreto is Institut für Pharmakologie und Toxikologie, Universität Freiburg, Albertstrasse 25, 79104, Freiburg i. Br., Germany. 
$\alpha_{1}$-AR subtypes have been generated, i.e., either the wildtype (WT) or the agonist-independent constitutively active $\alpha_{1}-A R(6)$. In the case of $\alpha_{1 B}-A R$, these models exhibited a certain degree of cardiac dysfunction/hypertrophy (7-11), although some studies have found clear-cut cardiac hypertrophy just at an advanced age (9-11). Interestingly, cardiac hypertrophy was also reported in systemic overexpression of constitutively active or WT $\alpha_{1 B}-A R$, a phenomenon not due to pressure load since these animals presented a normotensive (WT $\alpha_{1}$-AR) or even hypotensive (constitutively active $\left.\alpha_{1}-A R\right)$ phenotype $(12,13)$. In contrast, other studies have not detected any sign of cardiac hypertrophy in these models (14-17) or have observed them only after marked hypertrophic stimuli $(16,18)$, indicating that the function of $\alpha_{1 B}-A R$ in murine heart is still a debatable issue.

P-type ATPases are membrane-bound ion-transporting proteins that are vital for cell function and are particularly involved in myocardial ion homeostasis. It is well known that some members, such as $\mathrm{Na}^{+} / \mathrm{K}^{+}$-ATPase $\alpha_{2}$ isoform and sarco/endoplasmic reticulum $\mathrm{Ca}^{2+}$-ATPase (SERCA2), are down-regulated by cardiac stress associated with adrenergic stimulation and may progress to hypertrophy and failure $(19,20)$. For cardiac plasmalemmal $\mathrm{Ca}^{2+}$-ATPase (PMCA), an early expression increase and further decline apparently reflect an initial adaptation to facilitate calcium removal and are the basis of more persistent cardiac dysfunction, respectively (21).

Stress-induced changes mediated by persistent stressors may contribute to cardiac hypertrophy. In fact, an increasing number of intracellular signaling pathways have been described as important transducers of the hypertrophic response, such as the mitogen-activated protein kinases (MAPKs) (22). Recent studies indicate that $\alpha_{1}-A R$ may signal through MAPK pathways to stimulate growth responses in rat but not mouse cardiomyocytes (23). More importantly, MAPKs are also able to cross-talk and regulate intracellular calcium-handling proteins (24).

Because of the controversial role of cardiac $\alpha_{1 B}-A R$ and the absence of information regarding the specific regulatory function of this receptor on proteins involved in cardiac calcium homeostasis in vivo, we used transgenic mice that overexpress myocardial-targeted constitutively active mutant $\alpha_{1 \mathrm{~B}}-\mathrm{AR}\left(\mathrm{CAM} \alpha_{1 \mathrm{~B}}-\mathrm{AR}\right.$ mice) (7) in order to evaluate the activity and expression of cardiac ion transport ATPases $\left(\mathrm{Na}^{+} / \mathrm{K}^{+}\right.$-ATPase, SERCA and PMCA) and MAPKs (extracellular signal-regulated kinases, ERK1/2; c-Jun-Nterminal kinases, JNK1/2, and p38).

\section{Material and Methods}

\section{Animal model}

$\mathrm{CAM}_{1 \mathrm{~B}}-\mathrm{AR}$ transgenic male adult mice (10 to 12 weeks old; Jackson Laboratory, USA) were maintained and used (7). They harbored a genetic profile in which the mutant $\alpha_{1 B}$ gene was incorporated by non-homologous insertion through the $\alpha$-myosin heavy chain ( $\alpha-M H C$ ) promoter coupled to the coding sequence of $\mathrm{CAMa}_{1 \mathrm{~B}}-\mathrm{AR}$. Non-transgenic C57BL/6J mice (WT; Jackson Laboratory) served as controls. All animal procedures were approved by the Ethics Committee of Universidade Federal de São Paulo, in accordance with the Principles of Laboratory Animal Care published by the National Institutes of Health (NIH Publication \#86-23, revised 1996, USA).

\section{Tissue collection and membrane preparations}

Mice were weighed and their hearts excised, dissected, washed internally with a $320 \mathrm{mM}$ sucrose, $1 \mathrm{mM}$ EDTA and $5 \mathrm{mM}$ imidazole-HCl buffer, $\mathrm{pH} 7.2$, blotted on filter paper and weighed. Tissue samples were immediately frozen in liquid nitrogen and stored at $-80^{\circ} \mathrm{C}$ until use. Subcellular preparations were obtained as described (25). Organs from both transgenic and WT mice (approximately five hearts per preparation) were minced and homogenized in a 320 $\mathrm{mM}$ sucrose, $5 \mathrm{mM}$ imidazole- $\mathrm{HCl}$ buffer plus $0.1 \mathrm{mM}$ phenylmethylsulfonyl fluoride (PMSF; Sigma-Aldrich, USA) using an Ultraturrax disperser (9500 rpm for $10 \mathrm{~s}$ plus two steps of $13,500 \mathrm{rpm}$ for $10 \mathrm{~s}$ with a 20 -s interval between steps), followed by filtration through gauze and ultracentrifugation at $100,000 \mathrm{gav}_{\mathrm{v}}$ for $45 \mathrm{~min}$. A crude preparation was chosen because it is more suitable for quantification and comparison of molecular entities in muscles under conditions of plasticity, yielding a high and reproducible protein recovery (26). The pellet was resuspended in the same buffer without PMSF and stored at $-80^{\circ} \mathrm{C}$. Protein concentration was determined by the Lowry protein assay, using bovine serum albumin as standard.

\section{$\left[{ }^{3} \mathrm{H}\right]$-prazosin binding assay}

Saturation experiments were carried out at $25^{\circ} \mathrm{C}$ in $1 \mathrm{~mL}$ of a buffered solution, pH 7.4, containing $1 \mathrm{mM} \mathrm{EDTA,} 50 \mathrm{mM}$ Tris- $\left.\mathrm{HCl}, 0.5 \mathrm{nM} \mathrm{[}{ }^{3} \mathrm{H}\right]$-prazosin (specific activity $80 \mathrm{Ci} / \mathrm{mmol}$; New England Nuclear, USA) and increasing concentrations of unlabeled prazosin (0.1-20 nM), in parallel for both preparations $\left(\mathrm{CAMa}_{1 \mathrm{~B}}-\mathrm{AR}\right.$ and WT mice). This protocol, classically referred to as competition experiment, allows the use of lower amounts of radioligand and preparation (25). The reaction was started by adding $200 \mu \mathrm{g}$ protein and was stopped after $45 \mathrm{~min}$ by adding $4 \mathrm{~mL}$ ice-cold $5 \mathrm{mM}$ Tris-HCl buffer, $\mathrm{pH}$ 7.4 , twice and then subjected to vacuum filtration through a glass fiber filter (Filtrak GMF 3, Germany). Filters were then washed twice with $8 \mathrm{~mL}$ of the same buffer, dried and added to $10 \mathrm{~mL}$ of the scintillation solution (toluene containing 0.1 $\mathrm{g} / \mathrm{L}$ POPOP and $4.0 \mathrm{~g} / \mathrm{L}$ PPO). Radioactivity was then measured with a Tri-Carb liquid scintillation analyzer (Packard Instrument Co., USA). Nonspecific binding was determined in the presence of $1 \mu \mathrm{M}$ unlabeled prazosin.

\section{$\mathrm{Na}^{+} / \mathrm{K}^{+}$-ATPase activity}

The ATPase activity assay was performed at $37^{\circ} \mathrm{C}$ for $1 \mathrm{~h}$ and started by adding $20-40 \mu \mathrm{g}$ protein to a medium 
consisting of $20 \mathrm{mM}$ maleate-Tris buffer, $\mathrm{pH} 7.4,87.6 \mathrm{mM}$ $\mathrm{NaCl}, 3 \mathrm{mM} \mathrm{MgCl}_{2}, 1.2 \mathrm{mM} \mathrm{ATPNa}_{2}, 10 \mathrm{mM} \mathrm{NaN}_{3}$, and 1 $\mathrm{mM}$ EGTA in the presence of $3 \mathrm{mM} \mathrm{KCl}$ (total activity), or $1 \mathrm{mM}$ ouabain (ouabain-resistant activity; Sigma-Aldrich). ATPase activity was determined by measuring the release of inorganic phosphate (Pi) from ATP. The $\mathrm{Na}^{+} / \mathrm{K}^{+}$-ATPase activity was considered as the difference between total and ouabain-resistant ATPase activities (27).

\section{$\mathrm{Ca}^{2+}$-ATPase activity}

ATPase activity was assessed in a medium containing 5 mM Na${ }_{2}$ ATP, 0.3 mM EGTA, $4 \mathrm{mM} \mathrm{MgCl}_{2}, 10 \mathrm{mM} \mathrm{NaN}_{3}, 5$

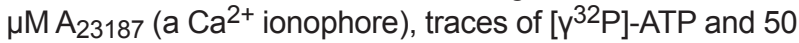
mM HEPES-Tris buffer, $\mathrm{pH} 7.4$, by measuring the radioactivity derived from the released [ $\left.{ }^{32} \mathrm{P}\right]-\mathrm{Pi}$. $\mathrm{Ca}^{2+}$-ATPase activity was calculated by subtracting the basal ATPase activity (measured in the absence of $\mathrm{Ca}^{2+}$ ) from the total ATPase activity (measured in the presence of $10 \mu \mathrm{M}$ free $\mathrm{Ca}^{2+}$, with or without 3 $\mu \mathrm{M}$ thapsigargin; Sigma-Aldrich). The thapsigargin-resistant $\mathrm{Ca}^{2+}$-ATPase activity (assumed to be due to PMCA pumps) was subtracted from the total $\mathrm{Ca}^{2+}$-ATPase activity to obtain the thapsigargin-sensitive $\mathrm{Ca}^{2+}$-ATPase activity (assumed to be due to SERCA pumps) (28).

\section{Immunoblotting assays}

Proteins were separated by $10 \%$ SDS-PAGE and electrotransferred to nitrocellulose membranes. Blots were incubated for $1 \mathrm{~h}$ in $5 \%$ non-fat dry milk dissolved in Tris-buffered saline solution containing $0.1 \%$ Tween 20 . Subsequently, membranes were incubated for $1 \mathrm{~h}$ at room temperature with one of the following primary antibodies: monoclonal mouse $\operatorname{lgG}$ anti- $\mathrm{Na}^{+} / \mathrm{K}^{+}$-ATPase $\alpha_{1}$ (McK1) and $\alpha_{2}$ (McB2) isoforms (Dr. K. Sweadner, Harvard Medical School, Boston, MA, USA), anti-PMCA (clone 5F10, Sigma Chemical, USA), anti-SERCA2 (Calbiochem, EMD Chemicals, USA) or polyclonal rabbit anti-total or phospho-MAPKs antibodies (ERK1/2, p38 or SAPK/JNK; Cell Signaling Technology, USA) and for $1 \mathrm{~h}$ with horseradish peroxidaseconjugated anti-mouse (ATPases) or anti-rabbit (MAPKs) antibody (Promega, USA). Proteins were detected using an ECL detection kit (GE Healthcare Life Sciences, USA) and blot images were captured with a Bio-Rad GS-700 Imaging Densitometer and analyzed using the Quantity One Imaging software (Bio-Rad Laboratories, USA) $(25,28)$. Loading control was performed by densitometric examination of Ponceau red staining as well as total MAPK blotting.

\section{Data analysis}

Values from equilibrium binding experiments (dissociation constant, $K_{\mathrm{d}}$, and maximal number of binding sites, $B_{\max }$ ) were calculated assuming the existence of one class of specific binding sites in the range of concentrations used, by means of computerized non-linear regression analysis of the untransformed data (Prism 4.0, GraphPad Software Inc., USA), as reported earlier (28). Statistical analysis for comparing transgenic to wild-type values was performed using the unpaired Student $t$-test $(\mathrm{P}<0.05)$.

\section{Results}

\section{Phenotype analysis of $\mathrm{CAMa}_{1 \mathrm{~B}}-\mathrm{AR}$ mice}

Increases in heart/body weight ratios are classically associated with the occurrence of myocardial hypertrophy $(7,25)$. A small but significant increase of this ratio $(22 \%)$ was observed in transgenic mice (WT $=3.95 \pm 0.05$ and $\mathrm{CAMa}_{1 \mathrm{~B}}-\mathrm{AR}=4.85 \pm 0.08 \mathrm{mg} / \mathrm{g}, \mathrm{N}=30 ; \mathrm{P}<0.01$ ), which resulted exclusively from an increase in cardiac mass (WT $=116.9 \pm 2.7$ and $\mathrm{CAMa}_{1 \mathrm{~B}}-\mathrm{AR}=148.0 \pm 3.3 \mathrm{~g}, \mathrm{~N}=30$; $\mathrm{P}<0.01$ ), as the body weight did not change (WT $=29.5$ \pm 0.4 and $\mathrm{CAMa}_{1 \mathrm{~B}}-\mathrm{AR}=30.5 \pm 0.3 \mathrm{~g}, \mathrm{~N}=30$ ). This mild hypertrophy is consistent with a previous report (7).

The quantification of $\alpha_{1 B}-A R$ tissue density is not possible due to the lack of a selective ligand for this subtype of $\alpha_{1}$-AR $(2,3,7)$. Therefore, the global estimation of such receptors through binding assays with $\left[{ }^{3} \mathrm{H}\right]$-prazosin or $\left[{ }^{3} \mathrm{H}\right]$ HEAT has become a consensual method (7). Data obtained in $\left[{ }^{3} \mathrm{H}\right]$-prazosin binding assays showed an increase in total $\alpha_{1}-\mathrm{AR}$ binding $\left(B_{\max }\right)$ of approximately $70 \%(\mathrm{WT}=123.7$ \pm 31.3 and $\mathrm{CAMa}_{1 \mathrm{~B}}-\mathrm{AR}=214.6 \pm 32.0 \mathrm{fmol} / \mathrm{mg}, \mathrm{N}=6 ; \mathrm{P}$ $<0.01$ ), indicating a significant increase of $\alpha_{1}-A R$ density in transgenic hearts.

\section{$\mathrm{Ca}^{2+}$-ATPase activity and protein expression}

Maximal cardiac $\mathrm{Ca}^{2+}$-ATPase activity was similar for WT and $C A M \alpha_{1}-A R$ mice (Table 1). On the other hand, the relative contribution of SERCA and PMCA to the total $\mathrm{Ca}^{2+}$-ATPase activity was statistically different: while in our preparation the contribution of the two $\mathrm{Ca}^{2+}$-ATPases was not different in WT mice, the thapsigargin-resistant PMCA contribution was significantly higher than the thapsigargin-sensitive SERCA contribution in transgenic mice (Table 1).

Table 1. Cardiac P-type ATPase activities of wild-type and myocardialtargeted constitutively active mutant $\alpha_{1 \mathrm{~B}}-\mathrm{AR}\left(\mathrm{CAM} \alpha_{1 \mathrm{~B}}-\mathrm{AR}\right)$ mice.

\begin{tabular}{lcc}
\hline & \multicolumn{2}{c}{$\begin{array}{c}\text { Enzyme activity } \\
\left(\mu \mathrm{mol} \mathrm{Pi} \cdot \mathrm{mg}_{\text {protein }}{ }^{-1} \cdot \mathrm{h}^{-1}\right)\end{array}$} \\
\cline { 2 - 3 } & Wild-type & $\mathrm{CAMa}_{1 \mathrm{~B}}$-AR \\
\hline Total $\mathrm{Ca}^{2+}$-ATPase & $6.98 \pm 2.92$ & $5.13 \pm 1.53$ \\
Thapsigargin-sensitive $\mathrm{Ca}^{2+}$-ATPase & $2.88 \pm 0.50$ & $1.07 \pm 0.73$ \\
Thapsigargin-resistant $\mathrm{Ca}^{2+}$-ATPase & $4.10 \pm 0.71$ & $4.06 \pm 0.48^{*}$ \\
Total $\mathrm{Na}^{+} / \mathrm{K}^{+}$-ATPase & $1.17 \pm 0.17$ & $1.30 \pm 0.16$ \\
\hline
\end{tabular}

Data are reported as means \pm SEM $(N=6$ preparations of 5 hearts each). ${ }^{*} \mathrm{P}<0.05$ compared to $\mathrm{CAMa}_{1 \mathrm{~B}}-\mathrm{AR}$ thapsigargin-sensitive $\mathrm{Ca}^{2+}$ ATPase (unpaired Student $t$-test). 

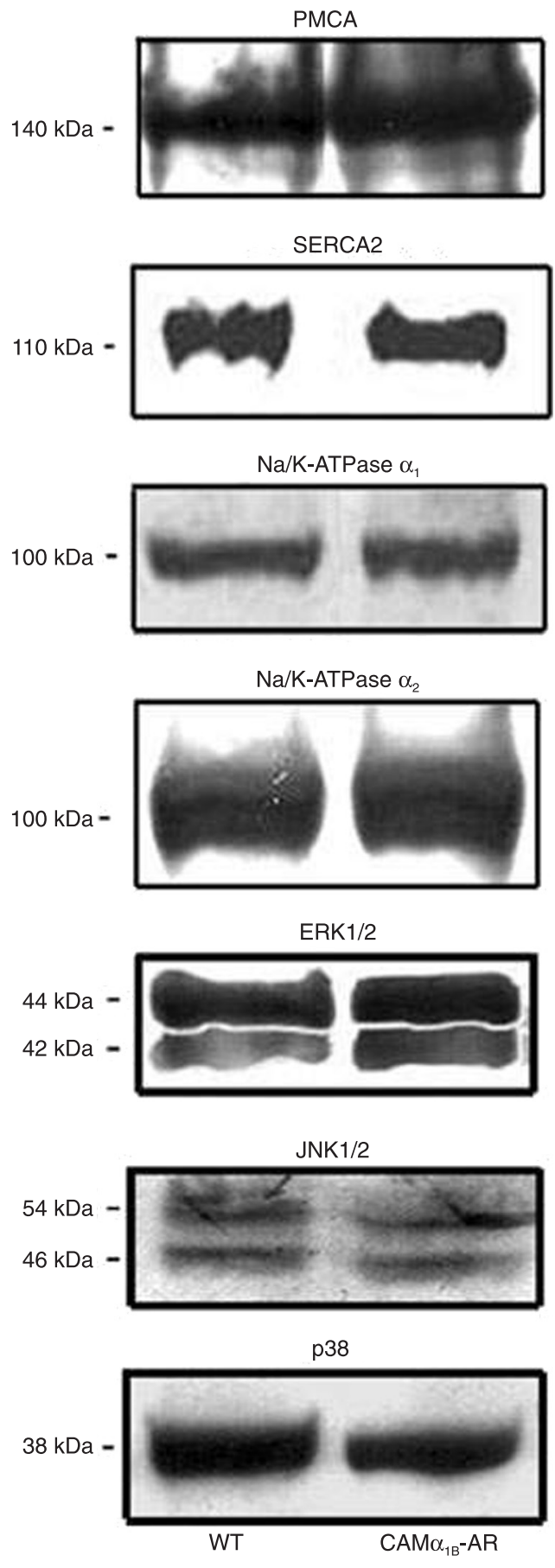

Figure 1. Protein expression of cardiac plasmalemmal (PMCA) and sarco/endoplasmic reticulum type 2 (SERCA2) $\mathrm{Ca}^{2+}$ ATPases, $\mathrm{Na}^{+} / \mathrm{K}^{+}$-ATPase $\alpha_{1}$ and $\alpha_{2}$ subunit isoforms and phosphorylated ERK1/2, JNK1/2 and p38. Representative blots of heart preparations from wild-type (WT) and myocardial-targeted

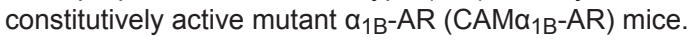

Western blot assays performed to determine the expression of the SERCA2 isoform in this model showed bands with similar relative absorbance in both groups (WT $=100 \pm 9$ and $\mathrm{CAMa}_{1 \mathrm{~B}}-\mathrm{AR}=108 \pm 5 \%, \mathrm{~N}=3$; Figure 1), in accordance with functional biochemical data. On the other hand, the amount of PMCA protein was significantly increased in transgenic heart preparations, i.e., about $30 \%$ compared to WT (WT = $100 \pm 7$ and $\mathrm{CAMa}_{1 \mathrm{~B}}-\mathrm{AR}=132 \pm$ $4 \%, N=6 ; P<0.05 ;$ Figure 1).

\section{$\mathrm{Na}^{+} / \mathrm{K}^{+}$-ATPase activity and protein expression}

Maximal $\mathrm{Na}^{+} / \mathrm{K}^{+}$-ATPase activity of heart preparations did not differ between groups (Table 1). Similarly, there was no significant difference between groups in the expression pattern of the two major cardiac a subunit isoforms of $\mathrm{Na}^{+}$/ $\mathrm{K}^{+}$-ATPase $\left(\alpha_{1}:\right.$ WT $=100 \pm 11$ and CAMa $_{1 \mathrm{~B}}-\mathrm{AR}=113 \pm$ $12 \%, N=6$; and $\alpha_{2}:$ WT $=100 \pm 8$ and $C A M \alpha_{1 B}-A R=115$ $\pm 7 \%, \mathrm{~N}=6$; Figure 1).

\section{Stress-signaling MAPK protein expression}

In order to determine whether MAPK pathways are activated in the present model of mild heart hypertrophy, we performed immunoblot assays to evaluate the expression of the three main MAPKs (ERK1/2, JNK1/2 and p38) in their activated (phosphorylated) form. All three MAPKs could be detected in every heart preparation. An equivalent expression pattern was found for both total (data not shown) and phosphorylated forms of ERK1/2 (WT = $100 \pm 11$ and $\left.\mathrm{CAMa}_{1 \mathrm{~B}}-\mathrm{AR}=91 \pm 11 \%, \mathrm{~N}=6\right), \mathrm{JNK} 1 / 2(\mathrm{WT}=100 \pm 13$ and $\left.\mathrm{CAMa}_{1 \mathrm{~B}}-\mathrm{AR}=88 \pm 9 \%, \mathrm{~N}=6\right)$ and p38 (WT = $100 \pm$ 10 and $\mathrm{CAMa}_{1 \mathrm{~B}}-\mathrm{AR}=106 \pm 6 \%, \mathrm{~N}=6$; Figure 1).

\section{Discussion}

Due to their lower density in mammalian hearts compared to the $\beta-A R$ and the lack of drugs with suitable selectivity, the role of $\alpha_{1}$-AR subtypes in cardiac function is still poorly understood. The hypertrophic effect of $\alpha_{1}-A R$ agonists on isolated rat cardiomyocytes has been known for a long time (4) and has been claimed to be mediated by the $\alpha_{1 A}-A R$ subtype (29). Nevertheless, results from transgenic mouse models indicated that $\alpha_{1 B}-A R$, but not $\alpha_{1 A}-A R$, is probably involved in the adaptive growth phenomenon in the heart $(2,3,6)$. In fact, the cardiac phenotype of the $\mathrm{CAMa}_{1 \mathrm{~B}}-\mathrm{AR}$ mice used in this study indicated a mild hypertrophy, in agreement with data reported by Milano et al. (7). Furthermore, binding data revealed a 1.7-fold increase of $\alpha_{1}$-AR density, similar to the 2- to 3-fold increase detected by others $(7,16)$. Interestingly, different reports described the absence of heart hypertrophy with the same model, probably because of epigenetic characteristics like diet and housing conditions, suggesting that myocardial $\alpha_{1 B}-A R$ activation per se would be a permissive more than a causative factor $(15,16)$. Considering our results (discussed below), we can presume that chronic cardiac $\alpha_{1 \mathrm{~B}}$-AR self-stimulation alone, 
at least at this age, is a weak inducer of pathological changes in the heart, as also deduced elsewhere $(6,9)$.

The present study revealed for the first time that the activity and expression of important cardiac P-type ATPases and MAPKs were predominantly unaltered in $C A M \alpha_{1 B}-A R$ mice. SERCA2 and $\mathrm{Na}^{+} / \mathrm{K}^{+}$-ATPase $\alpha_{2}$ isoform down-regulation has been observed in conditions of cardiac overload, $(19,20,25)$, with no change of the housekeeping $\mathrm{Na}^{+} / \mathrm{K}^{+}$ATPase $\alpha_{1}$ isoform $(17,25)$. Interestingly, cardiac-specific overexpression of WT $\alpha_{1 B}-A R(70$ - to 150-fold increase) did not affect SERCA2 mRNA content $(9,18)$, as it was reported at the initial hypertrophic stage (30). Our results also agree with previous reports showing that chronic $\alpha_{1}$-AR activation had no effect on $\mathrm{Na}^{+} / \mathrm{K}^{+}$-ATPase activity in vivo (31) or protein expression in vitro $(32,33)$. On the other hand, PMCA expression and PMCA-to-SERCA relative contribution to total $\mathrm{Ca}^{2+}$-ATPase activity increased in $\mathrm{CAMa}_{1 \mathrm{~B}}-\mathrm{AR}$ mice, suggesting that alterations of sarcolemmal calcium transport might be a maladaptive mechanism during the development of cardiac hypertrophy (34). Interestingly, PMCA has been associated with myocardial growth (35) and, via neuronal nitric oxide synthase, exacerbates the adrenergic-induced hypertrophy (36), suggesting the active contribution of this entity to progression of the disease.

MAPK activation plays a role in the regulation of the hypertrophic response in vivo, although it depends on the pathological stage, experimental model and type of stimulus (22). In comparable experimental models, activated MAPKs were only detected in very young but not in adult mice (3 and 12 weeks old, respectively) (37-39). ERK1/2 and/or JNK1/2 stimulation has been reported in cardiac-

\section{References}

1. Dzimiri N. Regulation of beta-adrenoceptor signaling in cardiac function and disease. Pharmacol Rev 1999; 51: 465-501.

2. Woodcock EA, Du XJ, Reichelt ME, Graham RM. Cardiac alpha 1-adrenergic drive in pathological remodelling. Cardiovasc Res 2008; 77: 452-462.

3. Du XJ. Distinct role of adrenoceptor subtypes in cardiac adaptation to chronic pressure overload. Clin Exp Pharmacol Physiol 2008; 35: 355-360

4. Simpson P. Stimulation of hypertrophy of cultured neonatal rat heart cells through an alpha 1-adrenergic receptor and induction of beating through an alpha 1 - and beta 1-adrenergic receptor interaction. Evidence for independent regulation of growth and beating. Circ Res 1985; 56: 884-894.

5. Iwaki K, Sukhatme VP, Shubeita HE, Chien KR. Alpha- and beta-adrenergic stimulation induces distinct patterns of immediate early gene expression in neonatal rat myocardial cells. fos/jun expression is associated with sarcomere assembly; Egr-1 induction is primarily an alpha 1-mediated response. J Biol Chem 1990; 265: 13809-13817.

6. Woodcock EA. Roles of alpha1A- and alpha1B-adrenoceptors in heart: insights from studies of genetically modified selective WT $\alpha_{1 \mathrm{~B}}-\mathrm{AR}(11)$ and systemic $C A M \alpha_{1 \mathrm{~B}}-\mathrm{AR}$ (13) overexpression. Nonetheless, a direct comparison with the present model should be considered with caution. Benoit et al. (11) showed a small but significant ERK1/2 activation, but not of the immediate upstream kinases MEK1/2, and their mice expressed huge amounts of $\alpha_{1 B}-A R$ (a 150-fold increase), which can lead to promiscuous receptor (trans) activation. Chalothorn et al. (13) detected ERK1/2 and JNK1/2 activation, but their animals exhibited autonomic failure and hypotension, which may evoke compensatory hypertensive mechanisms. This can significantly affect heart $\alpha_{1 \mathrm{~B}}-\mathrm{AR}$-independent signaling. Finally, persistent $\alpha_{1 B}-A R$ activation in vivo desensitizes the MAPK response in vitro (40).

The present results demonstrate that long-lasting stimulation of $\alpha_{1 B}-A R$ in murine heart provokes mild hypertrophy without a major influence on the expression of many proteins involved in cardiac homeostasis - transport ATPases $\left(\mathrm{Na}^{+} /\right.$ $\mathrm{K}^{+}$-ATPase and SERCA) and MAPKs (ERK1/2, JNK1/2 and p38) - but an up-regulation of PMCA, which may indicate an initial adaptation related to an emergent hypertrophic process. Considering that constitutive $\alpha_{1 \mathrm{~B}}-\mathrm{AR}$ activation persisted during the mouse lifetime, our findings might suggest that $\alpha_{1 \mathrm{~B}}-\mathrm{AR}$ probably has a minor pathophysiological function in the mouse heart.

\section{Acknowledgments}

Research supported by FAPERJ, FAPESP and CNPqPRONEX. A. Caricati-Neto, A. Jurkiewicz, C.L.M. Silva and F. Noël are recipients of CNPq research fellowships. mice. Clin Exp Pharmacol Physiol 2007; 34: 884-888.

7. Milano CA, Dolber PC, Rockman HA, Bond RA, Venable ME, Allen LF, et al. Myocardial expression of a constitutively active alpha 1B-adrenergic receptor in transgenic mice induces cardiac hypertrophy. Proc Natl Acad Sci U S A 1994; 91: 10109-10113.

8. Grupp IL, Lorenz JN, Walsh RA, Boivin GP, Rindt H. Overexpression of alpha1B-adrenergic receptor induces left ventricular dysfunction in the absence of hypertrophy. $\mathrm{Am} \mathrm{J}$ Physiol 1998; 275: H1338-H1350.

9. Lemire I, Ducharme A, Tardif JC, Poulin F, Jones LR, Allen $B G$, et al. Cardiac-directed overexpression of wild-type alpha1B-adrenergic receptor induces dilated cardiomyopathy. Am J Physiol Heart Circ Physiol 2001; 281: H931-H938.

10. Yun J, Zuscik MJ, Gonzalez-Cabrera P, McCune DF, Ross SA, Gaivin R, et al. Gene expression profiling of alpha(1b)adrenergic receptor-induced cardiac hypertrophy by oligonucleotide arrays. Cardiovasc Res 2003; 57: 443-455.

11. Benoit MJ, Rindt H, Allen BG. Cardiac-specific transgenic overexpression of alpha1B-adrenergic receptors induce chronic activation of ERK MAPK signalling. Biochem Cell Biol 2004; 82: 719-727. 
12. Zuscik MJ, Chalothorn D, Hellard D, Deighan C, McGee A, Daly CJ, et al. Hypotension, autonomic failure, and cardiac hypertrophy in transgenic mice overexpressing the alpha 1B-adrenergic receptor. J Biol Chem 2001; 276: 1373813743.

13. Chalothorn D, McCune DF, Edelmann SE, Tobita K, Keller $\mathrm{BB}$, Lasley $\mathrm{RD}$, et al. Differential cardiovascular regulatory activities of the alpha 1B- and alpha 1D-adrenoceptor subtypes. J Pharmacol Exp Ther 2003; 305: 1045-1053.

14. Akhter SA, Milano CA, Shotwell KF, Cho MC, Rockman HA, Lefkowitz RJ, et al. Transgenic mice with cardiac overexpression of alpha1B-adrenergic receptors. In vivo alpha1adrenergic receptor-mediated regulation of beta-adrenergic signaling. J Biol Chem 1997; 272: 21253-21259.

15. Harrison SN, Autelitano DJ, Wang BH, Milano C, Du XJ, Woodcock EA. Reduced reperfusion-induced Ins $(1,4,5) \mathrm{P} 3$ generation and arrhythmias in hearts expressing constitutively active alpha1B-adrenergic receptors. Circ Res 1998; 83: $1232-1240$.

16. Wang BH, Du XJ, Autelitano DJ, Milano CA, Woodcock EA. Adverse effects of constitutively active alpha(1B)-adrenergic receptors after pressure overload in mouse hearts. Am J Physiol Heart Circ Physiol 2000; 279: H1079-H1086.

17. Gao XM, Wang BH, Woodcock E, Du XJ. Expression of active alpha(1B)-adrenergic receptors in the heart does not alleviate ischemic reperfusion injury. $\mathrm{J} \mathrm{Mol}$ Cell Cardiol 2000; 32: 1679-1686.

18. laccarino G, Keys JR, Rapacciuolo A, Shotwell KF, Lefkowitz RJ, Rockman HA, et al. Regulation of myocardial betaARK1 expression in catecholamine-induced cardiac hypertrophy in transgenic mice overexpressing alpha1B-adrenergic receptors. J Am Coll Cardiol 2001; 38: 534-540.

19. Verdonck F, Volders PG, Vos MA, Sipido KR. Intracellular $\mathrm{Na}^{+}$and altered $\mathrm{Na}^{+}$transport mechanisms in cardiac hypertrophy and failure. J Mol Cell Cardiol 2003; 35: 5-25.

20. Arai M, Matsui H, Periasamy M. Sarcoplasmic reticulum gene expression in cardiac hypertrophy and heart failure. Circ Res 1994; 74: 555-564.

21. Lehotsky J, Kaplan P, Murin R, Raeymaekers L. The role of plasma membrane $\mathrm{Ca}^{2+}$ pumps (PMCAs) in pathologies of mammalian cells. Front Biosci 2002; 7: d53-d84.

22. Muslin AJ. MAPK signalling in cardiovascular health and disease: molecular mechanisms and therapeutic targets. Clin Sci 2008; 115: 203-218.

23. Sabri A, Pak E, Alcott SA, Wilson BA, Steinberg SF. Coupling function of endogenous alpha(1)- and beta-adrenergic receptors in mouse cardiomyocytes. Circ Res 2000; 86: 1047-1053.

24. Chakraborti S, Das S, Kar P, Ghosh B, Samanta K, Kolley $S$, et al. Calcium signaling phenomena in heart diseases: a perspective. Mol Cell Biochem 2007; 298: 1-40.

25. Quintas LEM, Noël F, Wibo M. $\mathrm{Na}^{+} / \mathrm{K}^{+}$-ATPase alpha isoforms expression in stroke-prone spontaneously hypertensive rat heart ventricles: effect of salt loading and lacidipine treatment. Eur J Pharmacol 2007; 565: 151-157.

26. Bambrick LL, Howlett SE, Feng ZP, Gordon T. Radioligand binding to muscle homogenates to quantify receptor and ion channel numbers. J Pharmacol Methods 1988; 20: 313-321.
27. Lopez LB, Quintas LEM, Noël F. Influence of development on $\mathrm{Na}(+) / \mathrm{K}(+)$-ATPase expression: isoform- and tissuedependency. Comp Biochem Physiol A Mol Integr Physiol 2002; 131: 323-333.

28. Quintas LEM, Cunha VMN, Scaramello CB, da Silva CL, Caricati-Neto A, Lafayette SS, et al. Adaptive expression pattern of different proteins involved in cellular calcium homeostasis in denervated rat vas deferens. Eur J Pharmacol 2005; 525: 54-59.

29. Autelitano DJ, Woodcock EA. Selective activation of alpha1A-adrenergic receptors in neonatal cardiac myocytes is sufficient to cause hypertrophy and differential regulation of alpha1-adrenergic receptor subtype mRNAs. $J$ Mol Cell Cardiol 1998; 30: 1515-1523.

30. Hasenfuss G. Alterations of calcium-regulatory proteins in heart failure. Cardiovasc Res 1998; 37: 279-289.

31. Baba A, Yoshikawa T, Nakamura I, Iwata M, Wainai Y, Ogawa S. Isoform-specific alterations in cardiac and erythrocyte $\mathrm{Na}^{+}, \mathrm{K}^{+}$-ATPase activity induced by norepinephrine. J Card Fail 1998; 4: 333-341.

32. Orlowski J, Lingrel JB. Thyroid and glucocorticoid hormones regulate the expression of multiple Na,K-ATPase genes in cultured neonatal rat cardiac myocytes. J Biol Chem 1990; 265: 3462-3470.

33. Quintas LEM, Lafayette SS, Caricati-Neto A, Jurkiewicz A, Noël F. Role of noradrenaline on the expression of the $\mathrm{Na}^{+} /$ $\mathrm{K}^{+}$-ATPase alpha2 isoform and the contractility of cultured rat vas deferens. Biochem Pharmacol 2002; 64: 14311437.

34. Moisin C, Balta N, Filcescu V, Dumitriu IF, Stoian G, Petec G. Activity of $\mathrm{Na}^{+} / \mathrm{K}^{+}$-ATPase and of $\mathrm{Ca}^{++}$-ATPase under the action of adenosine triphosphate in experimental myocardial hypertrophy. Rom J Physiol 1998; 35: 303-311.

35. Hammes A, Oberdorf-Maass S, Rother T, Nething K, Gollnick F, Linz KW, et al. Overexpression of the sarcolemmal calcium pump in the myocardium of transgenic rats. Circ Res 1998; 83: 877-888.

36. Oceandy D, Cartwright EJ, Emerson M, Prehar S, Baudoin FM, Zi M, et al. Neuronal nitric oxide synthase signaling in the heart is regulated by the sarcolemmal calcium pump $4 \mathrm{~b}$. Circulation 2007; 115: 483-492.

37. Minamino T, Yujiri T, Terada N, Taffet GE, Michael LH, Johnson $\mathrm{GL}$, et al. MEKK1 is essential for cardiac hypertrophy and dysfunction induced by Gq. Proc Natl Acad Sci U S A 2002; 99: 3866-3871.

38. Adams JW, Sakata Y, Davis MG, Sah VP, Wang Y, Liggett $\mathrm{SB}$, et al. Enhanced Galphaq signaling: a common pathway mediates cardiac hypertrophy and apoptotic heart failure. Proc Natl Acad Sci U S A 1998; 95: 10140-10145.

39. Hayashida W, Kihara $Y$, Yasaka A, Inagaki K, Iwanaga $Y$, Sasayama S. Stage-specific differential activation of mitogen-activated protein kinases in hypertrophied and failing rat hearts. J Mol Cell Cardiol 2001; 33: 733-744.

40. Chalothorn D, McCune DF, Edelmann SE, Garcia-Cazarin ML, Tsujimoto G, Piascik MT. Differences in the cellular localization and agonist-mediated internalization properties of the alpha(1)-adrenoceptor subtypes. Mol Pharmacol 2002; 61: 1008-1016. 